\title{
Prevalence and distribution of metabolic syndrome and its components among provinces and ethnic groups in Indonesia
}

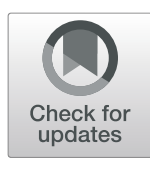

\author{
Elizabeth Henny Herningtyas ${ }^{1 *}$ (D) and Tian Sheng $\mathrm{Ng}^{2}$
}

\begin{abstract}
Background: Global increase of metabolic syndrome (MetS) may have affected Indonesia, however, lack of data in this multiethnic group country warrants a nationwide study for MetS and its components. This study aims to determine the prevalence of metabolic syndrome and its components among Indonesian people based on the province and ethnic groups.

Methods: We obtained 8573 subjects from the Indonesian Family Life Survey Wave 4 (IFLS4), spread over 20 provinces in Indonesia and consisting of 27 ethnic groups. MetS was operationalized according to an adapted Harmonized MetS definition. Prevalence ratios with 95\% confidence interval were estimated using log-binomial regression.
\end{abstract}

Results: The prevalence of MetS in Indonesia is $21.66 \%$ with provincial prevalence ranging from 0 to $50 \%$, while the ethnic prevalence ranging from 0 to $45.45 \%$. Significant higher MetS prevalence ratios were found in Jakarta (PR 1.826; 95Cl 1.628-2.048), West Nusa Tenggara (PR 1.412; 95Cl: 1.222-1.630), West Sumatra (PR 1.404; 95Cl: 1.202-1.641), East Java province (PR 1.109; 95Cl: 1.001-1.229) and in Sasak (PR 1.532; 95Cl:1.304-1.800), Minangkabau (PR 1.469; 95Cl:1.251-1.726), Betawi (PR 1.597; 95Cl:1.346-1.895), Acehnese ethnic group (PR 2.101; 95Cl:1.099-4.020) while significant lower prevalence ratios were observed in Central Java (PR 0.668; 95Cl: 0.580-0.770), Yogyakarta (PR 0.695; 95Cl: 0.575-0.840), Banten (PR 0.718; 95Cl: 0.533-0.968), Bali province (PR 0.724; 95Cl: 0.590-0.889) and in Javanese (PR 0.855; 95Cl:0.788-0.928), also Balinese ethnic groups (PR 0.669; 95Cl:0.535-0.836). The highest prevalence of MetS components among Indonesians was low HDL cholesterol (66.41\%), followed by hypertension (64.45\%), and central obesity (43.21\%).

Conclusions: The prevalence of MetS in Indonesia is moderate with provincial and ethnic prevalence varied. Provincial and ethnic group differences in MetS prevalence ratios were observed. The top two most prevalent MetS components in Indonesian were low HDL cholesterol and hypertension.

Keywords: Metabolic syndrome prevalence, MetS component distribution, Provinces in Indonesia, Indonesia's ethnic groups

\footnotetext{
* Correspondence: ehennyh@ugm.ac.id

${ }^{1}$ Clinical Pathology and Laboratory Medicine Department, Faculty of

Medicine, Public Health and Nursing, Universitas Gadjah Mada, Radioputro

Building 5th floor, Jalan Farmako, Sekip Utara, Yogyakarta, Indonesia

Full list of author information is available at the end of the article
}

(c) The Author(s). 2019 Open Access This article is distributed under the terms of the Creative Commons Attribution 4.0 International License (http://creativecommons.org/licenses/by/4.0/), which permits unrestricted use, distribution, and reproduction in any medium, provided you give appropriate credit to the original author(s) and the source, provide a link to the Creative Commons license, and indicate if changes were made. The Creative Commons Public Domain Dedication waiver (http://creativecommons.org/publicdomain/zero/1.0/) applies to the data made available in this article, unless otherwise stated. 


\section{Background}

Metabolic syndrome (MetS) is a cluster of interconnected risk factors that increase the risk of cardiovascular disease (CVD) and type 2 diabetes mellitus (T2DM) [1]. Increased prevalence worldwide affects both developed countries as well as developing countries, including the Asia-Pacific region [2]. This MetS increase is in concordance with the $82 \%$ increase of the worldwide obesity pandemic over the time span of 1990 to 2010 based on the Global Burden of Disease (GBD) [3]. According to a systemic review in 2007 by Ranasinghe et al. [2], the prevalence of MetS was in the range of 11.9 to $37.1 \%$ in the Asia-Pacific region which consists of the Philippines, China, Sri Lanka, Taiwan, Singapore, South Korea, Mongolia and Malaysia with the prevalence of $11.9,21.3,24.3,25.5,26.9,31.3,32.8$ and $37.1 \%$, respectively, based on different MetS syndrome definitions.

Among Southeast Asian countries, Indonesia is the most populated country in this region which reached 227 million people in 2005 [4], consisting of various ethnic groups that were estimated by 2007 to be 633 [5], along with various cultures and lifestyles spread over 33 provinces [6]. Since an increasing trend in MetS prevalence was found in other regions, Indonesia might be affected simultaneously, however, little is known regarding the MetS epidemiology in this multiethnic group country.

A few studies have tried to assess the MetS prevalence in certain provinces of Indonesia separately such as in Yogyakarta (13.19\%) [7], and Jakarta (28.4\%) [8], based on different MetS syndrome definitions but none yet have attempted the assessment in a larger scope such as a national survey. An update for MetS prevalence that represents MetS prevalence in a national scope is warranted and will benefit national planning for future prevention of MetS clinical consequences. Concerning the variations of Indonesian inhabitants and wide distribution of Indonesian lifestyles, it was hypothesized that the distribution of metabolic syndrome prevalence and MetS components may vary among provinces and ethnic groups in Indonesia.

Disability Adjusted Life Years (DALYs) contributed by risk factors associated with MetS including high BMI, high blood pressure, high fasting plasma glucose, high total cholesterol have grown since 1990 to 2000 based on GBD [3]. Low HDL cholesterol is the most prevalent risk factor, followed by central obesity, hypertension, high triglyceride level and high fasting plasma glucose level based on a Korean study in 2011 [9]. The prevalence pattern of MetS risk factors might differ in Indonesia due to different demographic and geographical factors and hence may affect the impact of each component involved in MetS based on different MetS definitions.

Thus, the aim of this study is to determine the prevalence of metabolic syndrome and MetS components among Indonesian people based on the province and ethnic groups.

\section{Methods \\ Study sites}

Indonesia is an archipelago country with an estimated population of 266,703,831 in 2018 (226,712,730 in 2005) by United Nations estimates that resides in $1,811,570$ $\mathrm{km}^{2}$ area and median age of population is 28.3 years [4]. Indonesia consists of 33 provinces in 2007 and 20 out of those 33 provinces were involved in this study [6].

\section{Data}

The participants in IFLS survey gave written informed consent according to the Institutional Review Board in National Institute of Health, USA. The usage of the IFLS datasheet had been approved by Institutional Review Board in Faculty of Medicine, Public Health and Nursing, Universitas Gadjah Mada. We combined data from various sources. For the individual data, we used the Indonesian Family Life Survey (IFLS) 4. The IFLS data were publicly available and can be retrieved in the RAND website (http://www.rand.org/labor/FLS/ IFLS.html).

The Indonesian Family Life Survey (IFLS) is a longitudinal survey conducted in Indonesia since 1995 and now reaches the Wave 5 that was conducted in 2013. The Fourth Wave of IFLS consisted of 50,580 subjects who originated from 7224 households by randomized stratified sampling in 1995 and had been expanded to 13,995 by the 2007 survey [10]. The required information in this study included the number of subjects, age, sex, waist circumference (WC), HDL cholesterol, height, weight, body mass index (BMI), systolic and diastolic blood pressure and the usage of medication for hypertension and diabetes. In this survey, the basic information on each household were location, sex, age and socio-demographic characteristics. Additionally, the physical health assessment data, which was done by two specially trained nurses in taking the health related measurements included height and weight in all subjects, waist and hip circumference in subjects 40 years and older, total and HDL cholesterol in subjects 40 years and older, along with blood pressure and pulse in subjects 15 years and older. The cholesterol level was measured by using the CardiochekPA system with capillary blood samples.

The subjects included in this study were aged 40 and above who are Indonesian citizens selected according to the IFLS 4 study, due to lack of WC and HDL-C data for subjects $<40$ years old. Subjects with incomplete data for collection of the research variables/risk factors and pregnant were excluded. The data was considered as incomplete data if there was no data on one or more of these variables: provincial code, gender, age, systolic and 
diastolic blood pressure, HDL-C, WC, ethnic group, and urban/rural status.

We used the Harmonized MetS definition from the Joint Interim Statement [1] which requires three out of five risk factors: central obesity, hypertension, low HDL cholesterol or evidence of cholesterol treatment, elevated triglyceride or evidence of elevated triglyceride treatment, and hyperglycemia or evidence of diabetes treatment. However, due to no data regarding elevated triglycerides, this risk factor was not present in the MetS components list in this study. Hence, the operational definition for this study was adapted by using three out of four existing components. Central obesity was defined by the Asian cut-off that uses the waist circumference $<90 \mathrm{~cm}$ for men and $<80 \mathrm{~cm}$ for women. Hypertension was defined as systolic blood pressure $\geq 130 \mathrm{mmHg}$ or diastolic $\mathrm{BP} \geq 85 \mathrm{mmHg}$ or treatment of previously diagnosed hypertension. Low HDL-cholesterol was defined as serum HDL-Cholesterol $<40 \mathrm{mg} / \mathrm{dL}$ in males, $<50 \mathrm{mg} / \mathrm{dL}$ in females or specific treatment for reduced HDL-Cholesterol. Diabetes treatment was employed as a substitute for insulin resistance due to lack of fasting plasma glucose data. Gender is defined as male or female. Age is classified into pre-elderly group (40 - <65 years old) and elderly group ( $\geq 60$ years old). Ethnicity is classified into Javanese, Sundanese, Balinese, Batak, Buginese, Chinese, Madurese, Sasak, Minangkabau, Banjarese, Bima-Dompu, Makassar, Nias, Palembang, Sumbawa, Toraja, Betawi, Dayak, Malay, Komering, Ambonese, Manado, Acehnese, Sumbagsel, Bantenese, Cirebonese and other ethnic groups. Geographic factor is classified into urban and rural status.

\section{Statistical analysis}

The data were analyzed using Stata v12.0 format software. Continuous variables were expressed as mean \pm standard deviation (SD). Student's t test or Mann-Whitney U-test was used to compare continuous variables. Categorical variables were reported as count and proportions. Proportions were tested using the chi-square test or Fisher's exact test, whenever appropriate.

Prevalence and prevalence ratio of MetS and their respective $95 \%$ confidence intervals $(95 \% \mathrm{CI})$ were estimated for gender, demographic characteristic, provinces and ethnic groups using log-binomial regression by comparing the reference group with the remaining subjects of the study population.

\section{Results}

\section{Basic characteristic of study Population}

The total amount of individuals in the target household of IFLS 4 was 50,580 subjects, however, only 44,103 subjects were interviewed. Among the 44,103 subjects, only 11,712 subjects age $>40$ years old from the IFLS 4 datasheet were included. After excluding subjects with incomplete data and in pregnancy, a total of 8573 subjects were obtained, consisting of 3886 males (45.33\%) and 4687 females (54.67\%). The baseline characteristics of study population are presented in Table 1. Among the estimated 633 ethnic groups in Indonesia, we obtained 26 major ethnic groups that were spread over 20 provinces out of 33 provinces in Indonesia in year 2007, and classified the remaining minor ethnic group subjects in "Others".

There were significant differences in demographic factors such as gender, average age, ethnic groups, and geographic factor between metabolic syndrome's group and non-metabolic syndrome group as well as anthropometric and laboratory characteristics. Metabolic syndrome group showed significant heavier body weight $(62.51 \pm 11.89$ vs. $54.40 \pm 9.863)$, larger BMI $(26.71 \pm 4.001$ vs. $22.77 \pm 3.487)$, larger waist circumference $(92.63 \pm 8.509$ vs. $80.12 \pm 9.741)$, higher systolic pressure $(154.4 \pm 22.58$ vs. $136.2 \pm 23.28)$ and diastolic blood pressure $(90.32 \pm 11.37$ vs. $81.46 \pm 11.43)$, lower HDL cholesterol level $(39.50 \pm 9.084$ vs. $42.23 \pm 15.18)$, higher proportion of subjects obtained lipid-lowering medication ( $0.7 \%$ vs. $0.09 \%)$, diabetes treatment $(3.18 \%$ vs. $0.16 \%$ ) and hypertension treatment (5.92\% vs. $1.58 \%$ ) than non-metabolic syndrome group (Table 1).

\section{Mapping of metabolic syndrome prevalence across Indonesia}

Among the studied provinces, most of the provinces (85\%) were located in the west part of Indonesia with higher population count which is comprised of 7 provinces on Sumatra island, 6 provinces on Java island, the Bali province and 3 provinces on Kalimantan island; while the east part of Indonesia was represented by 3 provinces that are comprised of 2 provinces on Sulawesi island and the small archipelago of West Nusa Tenggara province (Fig. 1).

When categorized in percentile categories, the map showed that 2 provinces in Indonesia had MetS prevalence higher than 30\% which were Jakarta, and East Kalimantan; 8 provinces had MetS prevalence in the range of $20.01-30 \%$ (North Sumatra, West Sumatra, Lampung, Bangka Belitung, East Java, West Nusa Tenggara, South Kalimantan, and South Sulawesi), while 7 provinces had MetS prevalence in the range of 10.01-20\% (South Sumatra, Kepulauan Riau, West Java, Central Java, Yogyakarta, Banten, and Bali), and 3 provinces had MetS prevalence less than 10\% (Riau, West Sulawesi, and Central Kalimantan) (Fig. 1).

\section{Distribution of ethic groups among provinces in Indonesia}

From the estimated 633 ethnic groups in Indonesia, we identified 27 ethnic groups that were spread over and 
Table 1 Baseline Characteristics of MetS components and demographic components of the study population

\begin{tabular}{|c|c|c|c|c|}
\hline Characteristics & Total (\%) & MetS (\%) & Non-MetS(\%) & $p$ \\
\hline \multicolumn{5}{|l|}{ Gender (\%) } \\
\hline Male & $3886(45.33)$ & $459(24.72)$ & $3427(51.03)$ & \multirow[t]{2}{*}{$<0.001$} \\
\hline Female & $4687(54.67)$ & $1398(75.28)$ & $3289(48.97)$ & \\
\hline \multicolumn{5}{|l|}{ Age Group } \\
\hline Pre-elderly & $6987(81.50)$ & $1491(80.29)$ & $5496(81.83)$ & \multirow[t]{2}{*}{0.129} \\
\hline Elderly & $1586(18.50)$ & $366(19.71)$ & $1220(18.17)$ & \\
\hline Average age (Mean \pm SD) & $53.77 \pm 10.99$ & $54.48 \pm 10.92$ & $53.57 \pm 11.01$ & 0.0017 \\
\hline \multicolumn{5}{|l|}{ Ethnic Group (\%) } \\
\hline Javanese & $3979(46.41)$ & $790(42.54)$ & $3189(47.48)$ & \multirow[t]{27}{*}{$<0.001$} \\
\hline Sundanese & $1022(11.92)$ & $220(11.85)$ & $802(11.94)$ & \\
\hline Balinese & $461(5.38)$ & $68(3.66)$ & $393(5.85)$ & \\
\hline Batak & $257(3)$ & $60(3.23)$ & $197(2.93)$ & \\
\hline Buginese & $303(3.53)$ & $61(3.28)$ & $242(3.60)$ & \\
\hline Chinese & $87(1.01)$ & $21(1.13)$ & $66(0.98)$ & \\
\hline Madurese & $285(3.32)$ & $57(3.07)$ & $228(3.39)$ & \\
\hline Sasak & $329(3.84)$ & $107(5.76)$ & $222(3.31)$ & \\
\hline Minangkabau & $349(4.07)$ & $109(5.87)$ & $240(3.57)$ & \\
\hline Banjarese & $215(2.51)$ & $49(2.64)$ & $166(2.47)$ & \\
\hline Bima-Dompu & 99 (1.15) & $21(1.13)$ & $78(1.16)$ & \\
\hline Makassar & $99(1.15)$ & $28(1.51)$ & $71(1.06)$ & \\
\hline Nias & $34(0.4)$ & $5(0.27)$ & $29(0.43)$ & \\
\hline Palembang & $32(0.37)$ & $8(0.43)$ & $24(0.36)$ & \\
\hline Sumbawa & $41(0.48)$ & $13(0.70)$ & $28(0.42)$ & \\
\hline Toraja & $45(0.52)$ & $12(0.65)$ & $33(0.49)$ & \\
\hline Betawi & $271(3.16)$ & $92(4.95)$ & $179(2.67)$ & \\
\hline Dayak & $6(0.07)$ & $0(0.00)$ & $6(0.09)$ & \\
\hline Malay & $60(0.7)$ & $12(0.65)$ & $48(0.71)$ & \\
\hline Komering & $6(0.07)$ & $1(0.05)$ & $5(0.07)$ & \\
\hline Ambon & $9(0.1)$ & $1(0.05)$ & $8(0.12)$ & \\
\hline Manado & $3(0.03)$ & $1(0.05)$ & $2(0.03)$ & \\
\hline Acehnese & $11(0.13)$ & $5(0.27)$ & $6(0.09)$ & \\
\hline Sumbagsel\# & $274(3.2)$ & $53(2.85)$ & $221(3.29)$ & \\
\hline Bantenese & $26(0.3)$ & $8(0.43)$ & $18(0.27)$ & \\
\hline Cirebonese & $161(1.88)$ & $26(1.40)$ & $135(2.01)$ & \\
\hline Others & 109 (1.27) & $29(1.56)$ & $80(1.19)$ & \\
\hline \multicolumn{5}{|l|}{ Geographic factor (\%) } \\
\hline Urban & $4526(52.79)$ & $1140(61.39)$ & $3386(50.42)$ & \multirow[t]{2}{*}{$<0.001$} \\
\hline Rural & $4047(47.21)$ & 717 (38.61) & $3330(49.58)$ & \\
\hline \multicolumn{5}{|c|}{ Anthropometric Parameter (Mean \pm SD) } \\
\hline Height (m) & $1.540 \pm 0.08353$ & $1.527 \pm 0.08056$ & $1.544 \pm 0.08396$ & $<0.0001$ \\
\hline Weight (kg) & $56.15 \pm 10.86$ & $62.51 \pm 11.89$ & $54.40 \pm 9.863$ & $<0.0001$ \\
\hline $\mathrm{BMI}\left(\mathrm{kg} / \mathrm{m}^{2}\right)$ & $23.62 \pm 3.952$ & $26.71 \pm 4.001$ & $22.77 \pm 3.487$ & $<0.0001$ \\
\hline$W C(\mathrm{~cm})$ & $82.83 \pm 10.79$ & $92.63 \pm 8.509$ & $80.12 \pm 9.741$ & $<0.0001$ \\
\hline
\end{tabular}

Blood Pressure (Mean \pm SD) 
Table 1 Baseline Characteristics of MetS components and demographic components of the study population (Continued)

\begin{tabular}{|c|c|c|c|c|}
\hline Characteristics & Total (\%) & MetS (\%) & Non-MetS(\%) & $p$ \\
\hline Systolic BP (mmHg) & $140.1 \pm 24.32$ & $154.4 \pm 22.58$ & $136.2 \pm 23.28$ & $<0.0001$ \\
\hline Diastolic BP (mmHg) & $83.38 \pm 11.98$ & $90.32 \pm 11.37$ & $81.46 \pm 11.43$ & $<0.0001$ \\
\hline \multicolumn{5}{|c|}{ Other Characteristics (Mean \pm SD or \%) } \\
\hline HDL-Cholesterol (mg/dl) & $40.56 \pm 14.43$ & $39.50 \pm 9.084$ & $42.23 \pm 15.18$ & $<0.0001$ \\
\hline Cholesterol treatment & $19(0.22)$ & $13(0.70)$ & $6(0.09)$ & $<0.001$ \\
\hline Diabetes treatment & $70(0.82)$ & $59(3.18)$ & $11(0.16)$ & $<0.001$ \\
\hline Hypertension treatment & $216(2.52)$ & $110(5.92)$ & $106(1.58)$ & $<0.001$ \\
\hline
\end{tabular}

aEthnic group names are based on Demography of Indonesia's Ethnicity book and IFLS 4 codebook's original name; \#Sumbagsel in southern Sumatra consists of Jambi and Bengkulu ethnic groups

inhabited 20 provinces. Among those identified ethnic groups, the Javanese ethnic group was the dominant one that reached approximately $46 \%$ of Indonesian inhabitants and lived in 19 out of 20 provinces with the highest percentage (99\%) in the Special Region of Yogyakarta. The Sundanese was the second highest ethnic group in Indonesia inhabiting 12 out of 20 provinces but most of them live in West Java (Fig. 2).

The other ethnic groups were distributed over 20 provinces with certain ethnic groups tending to be major inhabitants in certain provinces such as the Batak ethnic group was mostly residing in North Sumatra, Minang ethnic group in West Sumatra, Balinese in the Bali province, Bugis in South Sulawesi, and Sasak ethnic group in West Nusa Tenggara (Fig. 2).

\section{Prevalence and prevalence ratio of metabolic syndrome among provinces and ethnic groups}

The prevalence of MetS in Indonesia was 21.66\% (Table 2). The MetS prevalence was shown to be more than or equal to $20 \%$ in 11 out of 20 provinces in Indonesia (Table 2) and in 19 out of 27 ethnic groups

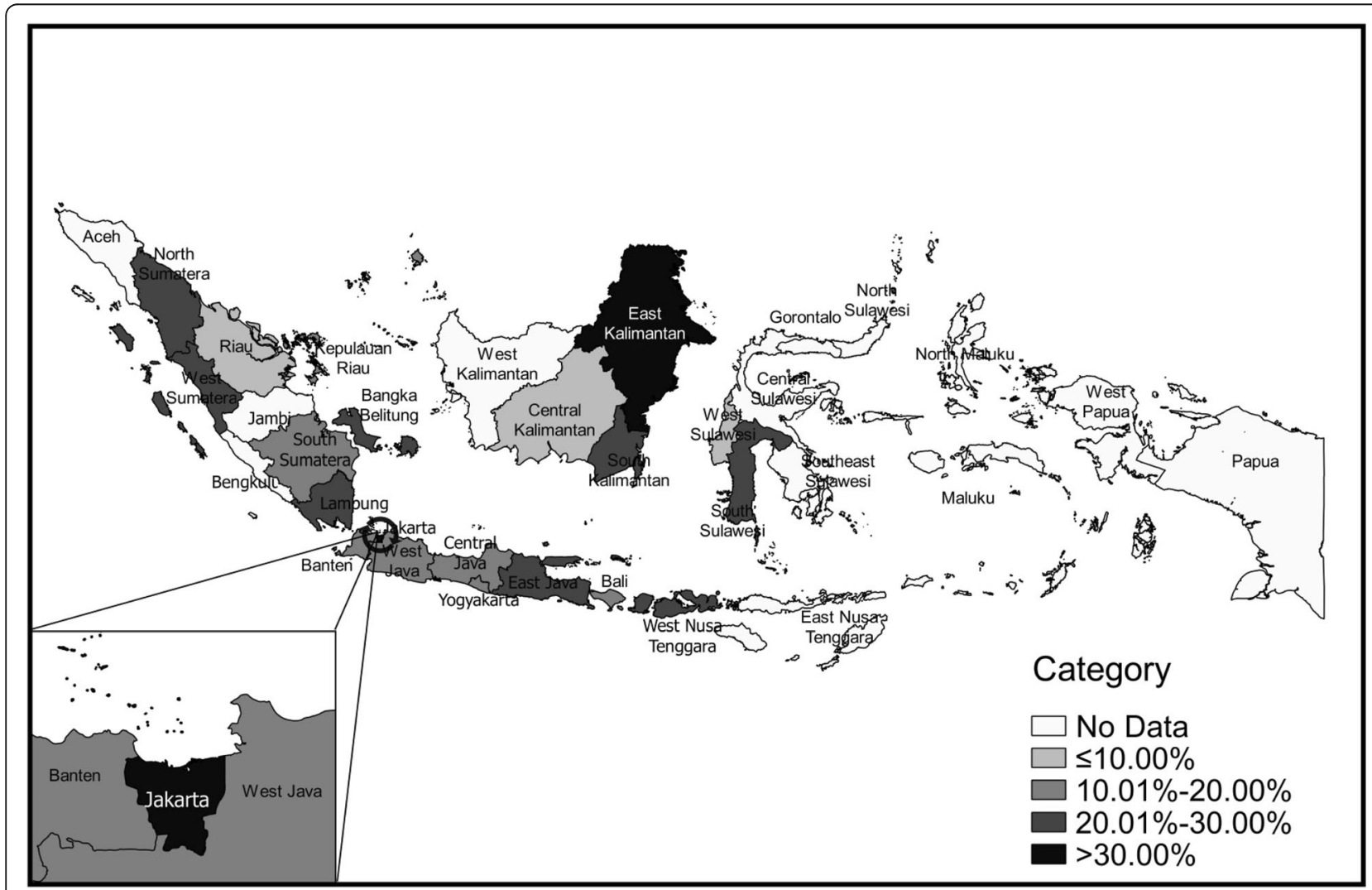

Fig. 1 Categorical Distribution of Metabolic Syndrome Prevalence among Provinces in Indonesia. Indonesia Map 2007 was obtained from www. big.go.id by request, further processed using the QGIS v2.18.10. Permission was obtained from Lutfan Lazuardi, MD. PhD for publication of the map 


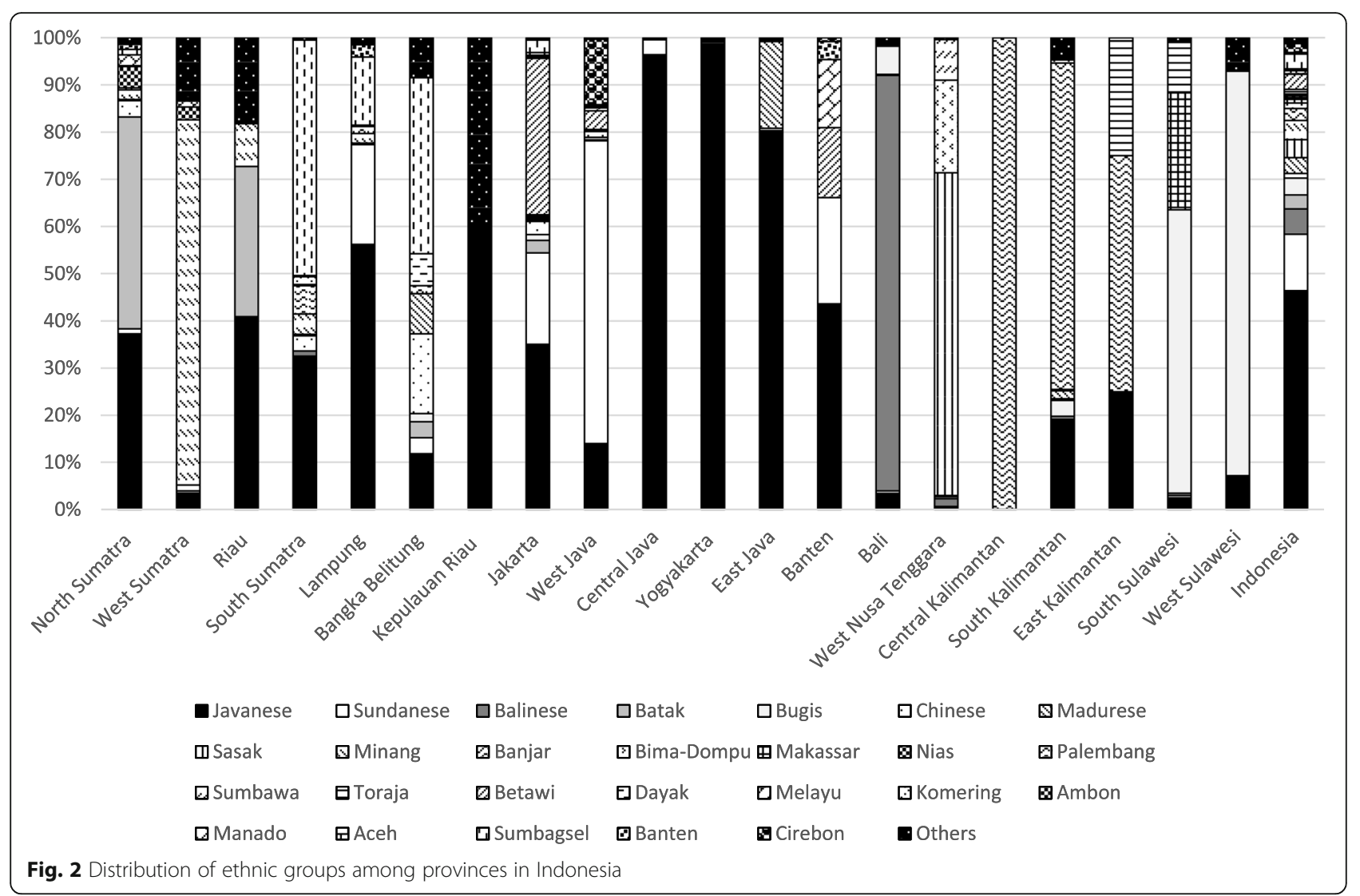

(Table 3). The majority of the subjects are found on Java Island (Banten, Jakarta, West Java, Central Java, Yogyakarta and East Java), covering more than 50\% of the total subjects, with MetS prevalence ranging from 15.16 to $37.50 \%$. followed by Sumatra Island (North Sumatra, West Sumatra, Riau, South Sumatra, Lampung, Bangka Belitung, and Kepulauan Riau) ranging from 9.09 to $29.85 \%$, Lesser Sunda Islands (Bali, West Nusa Tenggara) ranging from 15.94 to $29.89 \%$, Sulawesi Island (South Sulawesi and West Sulawesi) ranging from 7.14 to $22.83 \%$, and lastly Kalimantan Island (Central Kalimantan, South Kalimantan, and East Kalimantan) ranging from 0 to $50 \%$ (Table 2).

The prevalence ratio among provinces showed that 4 provinces had significant increment on the prevalence ratio which were Jakarta (PR 1.826; 95CI: 1.628-2.048), West Nusa Tenggara (PR 1.412; 95CI: 1.222-1.630), West Sumatra (PR 1.404; 95CI: 1.202-1.641), and East Java (PR 1.109; 95CI: 1.001-1.229), respectively, while another 4 provinces had significant decrement on the prevalence ratio which were Central Java (PR 0.668; 95CI: 0.580-0.770), Yogyakarta (PR 0.695; 95CI: 0.5750.840), Banten (PR 0.718; 95CI: 0.533-0.968) and Bali (PR 0.724; 95CI: 0.590-0.889), respectively (Table 2).

Based on the demographic factor, the prevalence ratio of demographic factors showed a significant higher prevalence ratio in females (PR 2.525; 95CI: 2.293-2.781), and in urban areas (PR 1.422; 95CI: 1.308-1.545) but no difference of prevalence ratio between pre-elderly and elderly. While based on ethnic groups, the significant higher prevalence ratios were found in Sasak (PR 1.532; 95CI: 1.304-1.800), Minangkabau (PR 1.469; 95CI: 1.251-1.726), Betawi (PR 1.597; 95CI: 1.346-1.895), and Acehnese ethnic group (PR 2.101; 95CI: 1.099-4.020). On the contrary, a significant lower prevalence ratio was observed in Javanese (PR 0.855; 95CI: 0.788-0.928), and the Balinese ethnic group (PR 0.669; 95CI: 0.535-0.836) (Table 3).

\section{Distribution of metabolic syndrome components among provinces and ethnic groups in Indonesia}

The highest prevalence of MetS component in Indonesia was low HDL cholesterol (66.41\%), followed by hypertension $(64.45 \%)$, central obesity $(43.21 \%)$ and insulin resistance (0.82\%) (Fig. 3).

Among the observed MetS components in this study, the most prevalent of MetS component was low HDL cholesterol which was found at prevalence of more than $50 \%$ in 18 out of 20 provinces in Indonesia and in 23 out of 27 ethnic groups involved (Fig. 3), while hypertension prevalence was found to be more than 50\% in 16 out of 20 provinces in Indonesia and in 23 out of 27 ethnic groups (Fig. 3). Central obesity prevalence was 
Table 2 Metabolic Syndrome Prevalence and Prevalence Ratio among Provinces in Indonesia

\begin{tabular}{|c|c|c|c|c|}
\hline Province Code & Province & Number of Subjects & MetS Prevalence, \% (95\% Cl) & MetS Prevalence Ratio, \% (95\% Cl) \\
\hline 12 & North Sumatra & 488 & 20.70 (17.09-24.30) & $0.953(0.797-1.139)$ \\
\hline 13 & West Sumatra & 402 & $29.85(25.36-34.34)$ & $1.404(1.202-1.641)^{a}$ \\
\hline 14 & Riau & 22 & $9.09(-3.96-22.14)$ & $0.419(0.112-1.572)$ \\
\hline 16 & South Sumatra & 369 & $19.78(15.70-23.87)$ & $0.910(0.738-1.122)$ \\
\hline 18 & Lampung & 340 & $20.59(16.27-24.91)$ & $0.949(0.767-1.173)$ \\
\hline 19 & Bangka Belitung & 59 & $22.03(11.14-32.93)$ & $1.017(0.628-1.647)$ \\
\hline 21 & Kepulauan Riau & 5 & $20.00(-35.53-75.53)$ & $0.923(0.160-5.332)$ \\
\hline 31 & Jakarta & 568 & $37.50(33.51-41.49)$ & $1.826(1.628-2.048)^{\mathrm{a}}$ \\
\hline 32 & West Java & 1141 & $19.54(17.24-21.85)$ & $0.889(0.784-1.008)$ \\
\hline 33 & Central Java & 1174 & $15.16(13.11-17.21)$ & $0.668(0.580-0.770)^{a}$ \\
\hline 34 & Yogyakarta & 617 & $15.40(12.54-18.25)$ & $0.695(0.575-0.840)^{\mathrm{a}}$ \\
\hline 35 & East Java & 1454 & $23.59(21.41-25.77)$ & $1.109(1.001-1.229)^{\mathrm{a}}$ \\
\hline 36 & Banten & 236 & $15.68(11.01-20.35)$ & $0.718(0.533-0.968)^{a}$ \\
\hline 51 & Bali & 502 & $15.94(12.72-19.15)$ & $0.724(0.590-0.889)^{a}$ \\
\hline 52 & West Nusa Tenggara & 475 & 29.89 (25.76-34.03 & $1.412(1.222-1.630)^{a}$ \\
\hline 62 & Central Kalimantan & 2 & 0 & 0 \\
\hline 63 & South Kalimantan & 298 & 23.83 (18.96-28.69) & $1.104(0.897-1.358)$ \\
\hline 64 & East Kalimantan & 4 & $50.00(-41.87-141.87)$ & $2.310(0.866-6.159)$ \\
\hline 73 & South Sulawesi & 403 & $22.83(18.71-26.94)$ & $1.057(0.879-1.270)$ \\
\hline \multirow[t]{2}{*}{76} & West Sulawesi & 14 & $7.14(-8.29-22.57)$ & $0.329(0.050-2.180)$ \\
\hline & Indonesia & 8573 & $21.66(20.79-22.55)$ & \\
\hline
\end{tabular}

Reference group: total population - targeted group

${ }^{a}$ Statistically significant prevalence ratio

The boldface in this table is emphasizing the total prevalence of MetS in Indonesia

found to be more or equal to $50 \%$ in 5 out of 20 provinces in Indonesia and in 12 out of 27 ethnic groups (Fig. 3). Diabetes treatment prevalence did not exceed $10 \%$ in any provinces in Indonesia nor in any ethnic groups (Fig. 3).

We had tried to determine MetS using 1, 2, 3, or 4 out of four components as the operational definition and we found that using one component made $91.78 \%$ of total subjects (7868 out of 8573 subjects) classified as MetS subjects, two components defined $61.11 \%$ of the total subjects (5239 out of 8573 subjects) as the MetS group, three components determined $21.66 \%$ of the total subjects as MetS subjects, and four components only defined 28 subjects as MetS subjects. (Additional file 1).

The two components definition gave around 39.45\% prevalence differences and almost 3 fold prevalence increment compared to three components definition. When we used the two components definition for demographic factors, provinces and ethnic groups, we found similar increment pattern (Additional files 2, 3 and 4). Thus, these findings potentially overestimated the MetS prevalence if we used two components definition and might greatly deviate from the 'true' MetS prevalence in Indonesia. Therefore, our current three components definition was more realistic although underestimation possibility was present. Hence, three out of four risk factors remained to be the operational definition in this study.

\section{Discussion}

This research is the first nationwide study regarding MetS prevalence in Indonesia. The prevalence of MetS in Indonesia was $21.66 \%$, which was in concordance with the estimation of global MetS prevalence $(20-25 \%)$ by IDF [11]. In the Asia-Pacific region, the highest prevalence was found to be in Malaysia (42.5\%, Harmonized definition) [12], followed by Mongolia (32.8\%, IDF) [13], South Korea (31.3\%, Harmonized definition) [14], China (29.7, NCEP ATP III) [15], Singapore (26.9, Harmonized Definition) [16], Taiwan (25.5, Modified NCEP ATP III) [17], Sri Lanka (24.3, IDF) [18], and Philippine (18.6\%, Modified NCEP ATP III) [19], so MetS prevalence in Indonesia is the second lowest in Asia Pacific region based on this study.

There is a significant gap between MetS prevalence in Western countries such as USA (39.0, IDF) [20] compared to MetS prevalence in Indonesia (21.66\%). It was shown that the national MetS prevalence in Indonesia $(21.66 \%)$ is less than the urban prevalence of MetS in 
Table 3 Metabolic syndrome prevalence and prevalence ratio based on demographic and ethnic group in Indonesia

\begin{tabular}{|c|c|c|c|c|}
\hline \multicolumn{2}{|l|}{ Characteristic } & \multirow{2}{*}{$\begin{array}{l}\text { Subjects Number } \\
3886(45.33)\end{array}$} & \multirow{2}{*}{$\begin{array}{l}\text { MetS Prevalence, \% (95\% Cl) } \\
11.81(10.80-12.83)\end{array}$} & \multirow{2}{*}{$\frac{\text { MetS Prevalence Ratio, \% (95\% Cl) }}{0.396(0.360-0.436)^{\mathrm{a}}}$} \\
\hline Gender & Male & & & \\
\hline & Female & $4687(54.67)$ & $29.83(28.52-31.14)$ & $2.525(2.293-2.781)^{a}$ \\
\hline \multirow[t]{2}{*}{ Age group } & Pre-elderly & $6987(81.50)$ & $21.05(20.38-22.30)$ & $0.925(0.836-1.022)$ \\
\hline & Elderly & $1586(18.50)$ & $23.29(21.00-25.15)$ & 1.081 (0.978-1.196) \\
\hline \multirow[t]{2}{*}{ Geographic factor } & Urban & $4526(52.79)$ & $25.19(23.92-26.45)$ & $1.422(1.308-1.545)^{a}$ \\
\hline & Rural & $4047(47.21)$ & $17.72(16.54-18.89)$ & $0.703(0.647-0.764)^{a}$ \\
\hline \multirow[t]{27}{*}{ Ethnic Group } & Javanese & 3979 (46.41) & $19.85(18.61-21.09)$ & $0.855(0.788-0.928)^{a}$ \\
\hline & Sundanese & $1022(11.92)$ & $21.53(19.00-24.05)$ & $0.993(0.877-1.245)$ \\
\hline & Balinese & $461(5.38)$ & $14.75(11.50-18.00)$ & $0.669(0.535-0.836)^{\mathrm{a}}$ \\
\hline & Batak & $257(3)$ & 23.35 (18.14-28.55) & $1.080(0.862-1.353)$ \\
\hline & Buginese & $303(3.53)$ & $20.13(15.59-24.67)$ & $0.927(0.738-1.164)$ \\
\hline & Chinese & $87(1.01)$ & $24.14(14.96-33.31)$ & $1.116(0.767-1.623)$ \\
\hline & Madurese & $285(3.32)$ & $20.00(15.33-24.67)$ & $0.921(0.727-1.166)$ \\
\hline & Sasak & $329(3.84)$ & $32.52(27.43-37.61)$ & $1.532(1.304-1.800)^{\mathrm{a}}$ \\
\hline & Minangkabau & $349(4.07)$ & $31.23(26.35-36.12)$ & $1.469(1.251-1.726)^{\mathrm{a}}$ \\
\hline & Banjarese & $215(2.51)$ & $22.79(17.14-28.44)$ & $1.054(0.821-1.352)$ \\
\hline & Bima-Dompu & $99(1.15)$ & $21.21(13.02-29.41)$ & $0.979(0.668-1.434)$ \\
\hline & Makassar & $99(1.15)$ & $28.28(19.26-37.31)$ & $1.310(0.955-1.798)$ \\
\hline & Nias & $34(0.4)$ & $14.71(2.16-27.25)$ & $0.678(0.301-1.525)$ \\
\hline & Palembang & $32(0.37)$ & $25.00(9.13-40.86)$ & $1.155(0.633-2.107)$ \\
\hline & Sumbawa & $41(0.48)$ & $31.71(16.84-46.58)$ & $1.467(0.934-2.303)$ \\
\hline & Toraja & $45(0.52)$ & $26.67(13.23-40.10)$ & $1.233(0.758-2.004)$ \\
\hline & Betawi & $271(3.16)$ & $33.95(28.27-39.62)$ & $1.597(1.346-1.895)^{\mathrm{a}}$ \\
\hline & Dayak & $6(0.07)$ & 0 & 0 \\
\hline & Malay & $60(0.7)$ & $20.00(9.58-30.42)$ & $0.923(0.555-1.533)$ \\
\hline & Komering & $6(0.07)$ & $16.67(-26.18-59.51)$ & $0.769(0.128-4.606)$ \\
\hline & Ambon & $9(0.1)$ & $11.11(-14.51-36.73)$ & $0.513(0.081-3.255)$ \\
\hline & Manado & $3(0.03)$ & $33.33(-110.09-176.76)$ & $1.539(0.310-7.630)$ \\
\hline & Acehnese & $11(0.13)$ & $45.45(10.37-80.54)$ & $2.101(1.099-4.020)^{\mathrm{a}}$ \\
\hline & Sumbagsel & $274(3.2)$ & $19.34(14.64-24.05)$ & $0.890(0.696-1.137)$ \\
\hline & Bantenese & $26(0.3)$ & $30.77(11.76-49.78)$ & $1.422(0.798-2.535)$ \\
\hline & Cirebonese & $161(1.88)$ & $16.15(10.40-21.89)$ & $0.742(0.521-1.057)$ \\
\hline & Others & 109 (1.27) & $26.61(18.18-35.03)$ & $1.232(0.900-1.687)$ \\
\hline
\end{tabular}

Reference group: total population - targeted group

${ }^{\mathrm{a}}$ Statistically significant prevalence ratio.

Jakarta (28.4\%) [8], being the capital of Indonesia, hence the latter could not represent the overall prevalence of MetS in Indonesia as demographic factors play significant roles in MetS prevalence. Nevertheless, the prevalence of MetS in Jakarta in this study was $37.5 \%$ based on the 2007 survey, which showed higher prevalence compared to the previous study in Jakarta (28.4\%) [8], based on the 2006 survey. Therefore, this prevalence difference gave an impression that there is a rising trend in MetS prevalence in Indonesia throughout the years.
Large MetS prevalence difference was seen in Kalimantan Island which was partly due to the limited amount of subjects representing each province. Some subjects were excluded in this study since their data were incomplete, which further reduced the sample size pool. The highest prevalence of MetS when compared among provinces was found in East Kalimantan (50\%) followed by Jakarta (37.50\%). Despite having only a small number of subjects in East Kalimantan who represented the province, the results were accepted because the data 


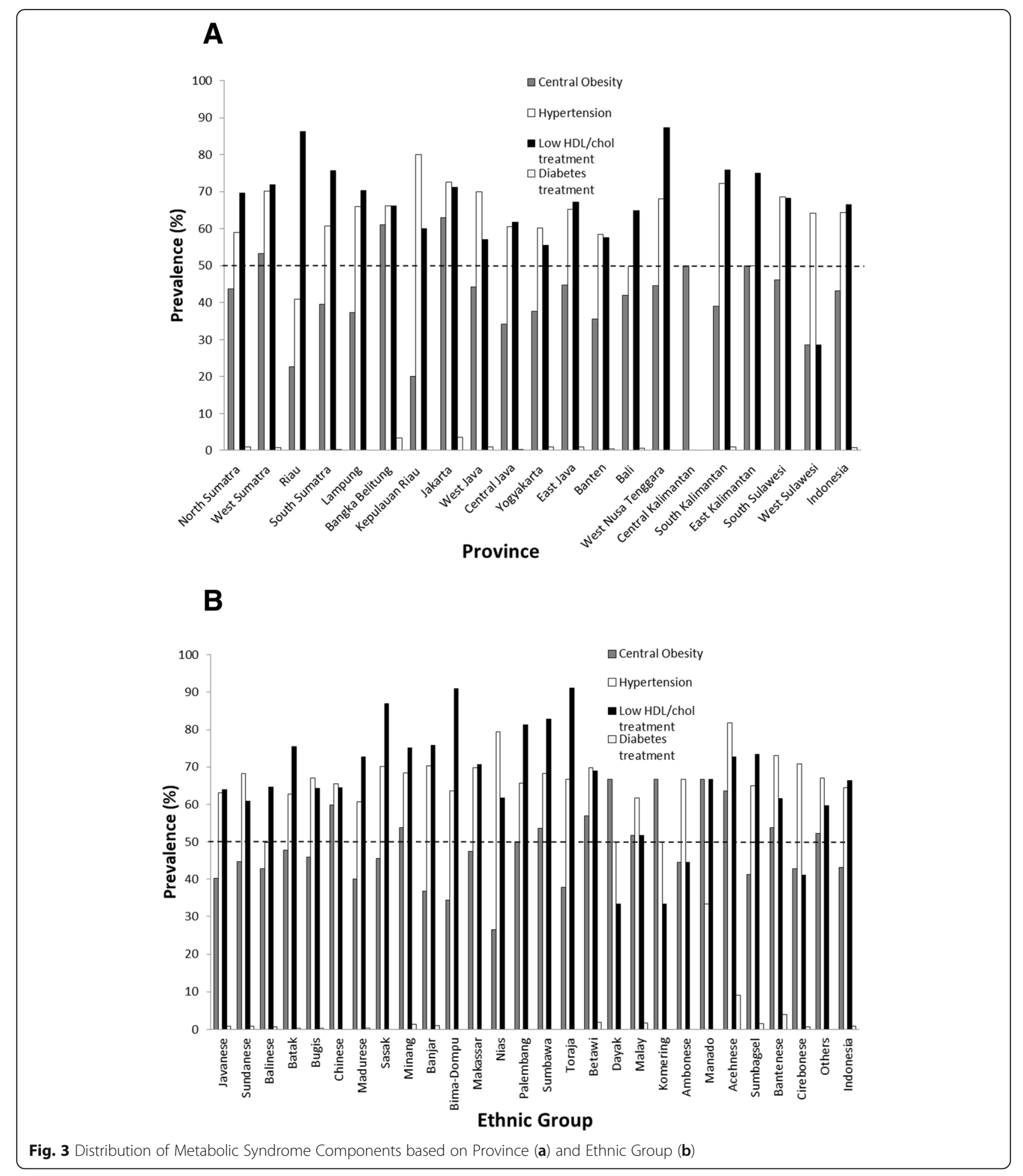

obtained from IFLS 4 are based on stratified random sampling which aimed to ensure estimates can be done with equal accuracy since population disparities were evident across provinces in Indonesia. This trend was consistent with one study which shown that Asians are more likely to manifest MetS compared to
non-Hispanic Whites [21] especially when Indonesians had gradually adopted western lifestyles including diet.

As most subjects in this study were residing on Java island, it was not surprising that Javanese was the largest ethnic group in this study which represented $46.41 \%$ of the total subjects. Each province tend to have 
its own unique ethnic group which was the dominant population. This dominant residency pattern might contribute to disparity in MetS prevalence among ethnic groups since each ethnic group might have different lipid profiles, socioeconomics and lifestyle, similar as in the previous studies [22-24]. The prevalence of MetS in Balinese is 0.67 times less than the remaining population, followed by Javanese which was 0.86 times less than the remaining population, showing lesser prevalence in these two ethnic groups. The prevalence of MetS in Acehnese was 2.1 times greater than the remaining population, followed by Sasak (1.53 times greater), Betawi (1.60 times greater) and Minangkabau (1.469 times greater). This finding tallied with the results from a study regarding lipid profiles among four ethnic groups including Minangkabau, Sundanese, Javanese and Buginese, revealed the Minangkabau ethnic group has the highest total plasma cholesterol and lowest plasma LDL cholesterol, Sundanese have the lowest plasma HDL cholesterol and Javanese have the lowest total and LDL plasma cholesterol and highest HDL plasma cholesterol [22]. Since the Javanese group had the best lipid profile, it is consonant with the finding in this study which shown MetS prevalence is significantly lower in the Javanese ethnic group compared to others. In a related study lipid profiles were consistently associated with insulin resistance because insulin affects the metabolism of HDL plasma cholesterol and triglycerides [25], hence central obesity is further developed with poor glucose and lipid control.

The top 3 most prevalent MetS components in this study were low HDL cholesterol, followed by hypertension and central obesity. This pattern was similar to one of the South America countries, Brazil, with low HDL cholesterol as the most prevalent component (59.3\%), followed by hypertension (52.5\%), and central obesity (38.9\%) [26]. However, European countries such as Poland, displayed a different pattern starting from top to bottom, abdominal obesity (75.1\%), hypertension (71\%) and insulin resistance (37.3\%) [27]. In Asian countries such as China, the most prevalent component was hypertension (24.52\%), followed by dyslipidemia (24\%) and central obesity (22.07\%) [28]. Furthermore, Malaysia showed a reverse arrangement for the top 3 components, which were abdominal obesity $(57.4 \%)$, hypertension (52.3\%) and low HDL cholesterol (42.7\%) [12]. Each country held a different pattern for the prevalence of each metabolic syndrome component, and even Malaysia as a neighbor country in the same continent showed dissimilarity, hence it is unlikely to have a standard pattern framed on each population due to wide variations of cultural background, demographic and socioeconomic factors.

Even when the low HDL cholesterol, hypertension and central obesity's pattern was brought forward to compare among Indonesia provinces, this pattern did not apply in certain provinces such as Kepulauan Riau, Jakarta, West Java, Yogyakarta, Banten, Central Kalimantan, South Sulawesi and West Sulawesi (8 out of 20 province). It was also different in certain ethnic groups such as Sundanese, Bugis, Chinese, Nias, Toraja, Dayak, Malay, Komering, Ambonese, Manado, Acehnese, Bantenese, Cirebonese and other minority ethnic groups (14 out of 27 ethnic groups). This pattern disparity definitely had effect on the criteria used to define MetS. Central obesity was not the most prevalence component, hence by using the IDF criteria which required central obesity as a core component [11] might potentially leave out MetS subjects, which reduces the sensitivity of screening the population. However, the specific racial cut-off values for waist circumference is valuable for Asian populations as NCEP ATP III criteria had a higher cut-off value for which the latter might not include the potential MetS subjects. Therefore, the Harmonized definition was applied in this study which required 3 out of 5 risk factors in addition to specific racial cut-off values for waist circumference. This approach was consistent with the finding that shown the Harmonized definition had the highest sensitivity [29] compared to IDF and NCEP ATP III criteria. The Body Mass Index (BMI) for defining obesity in Asian populations is also lower than in Caucasian populations since the percentage of body fat is higher in Asians, as Asian population are more likely to develop T2DM and CVD at BMI ranging $22-25 \mathrm{~kg} / \mathrm{m}^{2}$ [30], therefore it is necessary to implement lower cut-off values for waist circumference in Asian populations.

Limitations of this study include the lack of plasma triglyceride data which reduced one component from the 5 risk factors. Low HDL plasma cholesterol level does not indicate the presence of high plasma triglyceride in Indonesians, which is consistent with the finding based on a study which shown low HDL plasma cholesterol and normal triglyceride level in most of the West Africans and American Africans manifested with MetS [31]. Hence, it is possible to find a pattern of high plasma triglyceride level with normal HDL plasma cholesterol subjects who may not be classified as MetS subjects. There is also no fasting plasma glucose data which reduces the hyperglycemia sample size pool, rendering the possibility of leaving out potential MetS subjects with hyperglycemia. For the cholesterol treatment, the drug class is not specified in the datasheet. Thus, we cannot differentiate whether the treatment was meant for reduced HDL-cholesterol, elevated triglyceride or elevated LDL-cholesterol. Limited amount of subjects in certain provinces further reduces the specificity of MetS prevalence, which probably results in an over-estimate or under-estimate of the MetS prevalence in those provinces. Since this study showed approximately 1 MetS Indonesian 
were found among every 5 Indonesians in year 2007, this finding was alarming that the exact national MetS prevalence might be higher than estimated. Furthermore, the potential underestimation of this study was definitely more superior than extrapolating from sporadic provincial studies which were deemed inconclusive.

Since this is the first nationwide study of MetS prevalence, population based strategies should be implemented to control the expansion of MetS prevalence. MetS subjects had higher medical care utilization and costs compared to non-MetS subjects which increase approximately $24 \%$ in costs with each additional risk factor [32]. Furthermore, the stakeholders related to IFLS could include fasting plasma glucose and plasma triglyceride levels in future data collections because both components are important health determinants related to $\mathrm{CVD}$ and T2DM and more accurate MetS incidence can be determined.

\section{Conclusion}

The prevalence of MetS in Indonesia is moderate with provincial and ethnic prevalence varied. Provincial and ethnic group differences in MetS prevalence ratios were observed. The top two most prevalent MetSomponents in Indonesian were low HDL cholesterol and hypertension.

\section{Additional files}

Additional file 1: Determination of MetS prevalence by the presence of Components Number. (DOCX $12 \mathrm{~kb}$ )

Additional file 2: Metabolic syndrome prevalence and prevalence ratio based on demographic and ethnic group in Indonesia when using 2 component as MetS definition. (DOCX $16 \mathrm{~kb}$ )

Additional file 3: Distribution of Metabolic Syndrome Components based on Province. (DOCX $16 \mathrm{~kb}$ )

Additional file 4: Distribution of Metabolic Syndrome Components based on Ethnic Group. (DOCX 15 kb)

\section{Abbreviations \\ BMI: Body Mass Index; CVD: Cardiovascular Disease; DALYs: Disability Adjusted Life Years; GBD: Global Burden of Disease; HDL: High Density Lipoprotein; IDF: International Diabetes Federation; IFLS: Indonesian Family Life Survey; LDL: Low Density Lipoprotein; MetS: Metabolic Syndrome; NCEP ATP III: National Cholesterol Education Program Adult Treatment Panel III; T2DM: Type 2 Diabetes Mellitus; WC: Waist Circumference}

\section{Acknowledgements}

We thanks to Lutfan Lazuardi, MD. PhD for his teaching on mapping software and generous share of an Indonesian map from www.big.go.id.

\section{Funding}

This study has not been supported by any funding.

\section{Availability of data and materials}

The datasets that support the findings of this study are publicly available and can be retrieved from the RAND website (http://www.rand.org/labor/FLS/ IFLS.html) by registering first to that website for data retrieval.

\section{Authors' contributions}

$\mathrm{EHH}$ designed the study, analyzed the results, drafting the manuscript and reviewing the manuscript. TSN analyzed the data statistically, and drafting the manuscript. All of the authors have read and approved the final version of this manuscript.

\section{Ethics approval and consent to participate}

The participants in IFLS survey gave written informed consent according to the Ethical Review Board in National Institute of Health, USA. The usage of the IFLS datasheet had been approved by Institutional Review Board in Faculty of Medicine, Public Health and Nursing, Universitas Gadjah Mada.

\section{Consent for publication}

Not applicable.

\section{Competing interests}

The authors declare that they have no competing interests.

\section{Publisher's Note}

Springer Nature remains neutral with regard to jurisdictional claims in published maps and institutional affiliations.

\section{Author details}

${ }^{1}$ Clinical Pathology and Laboratory Medicine Department, Faculty of Medicine, Public Health and Nursing, Universitas Gadjah Mada, Radioputro Building 5th floor, Jalan Farmako, Sekip Utara, Yogyakarta, Indonesia. ${ }^{2}$ Undergraduate Program, Faculty of Medicine, Public Health and Nursing, Universitas Gadjah Mada, Grha Wiyata Building, Jalan Farmako, Sekip Utara, Yogyakarta, Indonesia.

Received: 25 July 2018 Accepted: 27 March 2019

Published online: 03 April 2019

\section{References}

1. Alberti KGMM, Eckel RH, Grundy SM, et al. Harmonizing the metabolic syndrome: a joint interim statement of the international diabetes federation task force on epidemiology and prevention; National Heart, Lung, and Blood Institute; American Heart Association; world heart federation; international. Circulation. 2009;120(16):1640-5 https://doi.org/10.1161/ CIRCULATIONAHA.109.192644.

2. Ranasinghe $P$, Mathangasinghe $Y$, Jayawardena R, Hills AP, Misra A. Prevalence and trends of metabolic syndrome among adults in the asiapacific region: a systematic review. BMC Public Health. 2017;17(101) https:// doi.org/10.1186/s12889-017-4041-1.

3. Institute for Health Metrics and Evaluation. The global burden of disease: generating evidence, guiding policy. 2013. http://www.healthdata.org/sites/ default/files/files/policy_report/2013/GBD_GeneratingEvidence/IHME_GBD_ GeneratingEvidence_FullReport.pdf.

4. Indonesia Population (2018) - Worldometers. http://www.worldometers.info/ world-population/indonesia-population/Accessed 21 Jun 2018.

5. Ananta A, Arifin EN, Hasbullah MS, Pramono A, Handayani NB. Demography of Indonesia's ethnicity: Institute of Southeast Asian Studies; 2015.

6. Bahan Paparan Riset Kesehatan Dasar (RISKESDAS) 2007, 2010, 2013. http:// labdata.litbang.depkes.go.id/23-labmandat/399-bahan-paparan-risetkesehatan-dasar-riskesdas-2007-2010-2013/Accessed 21 Jun 2018.

7. Jian $\mathrm{CH}$, Dewi FST, Herningtyas EH. Prevalence of metabolic syndrome and its components based on international diabetes federation (IDF) definition in Yogyakarta special region, Indonesia. J the Med Sci. 2017;49:128-40 https://doi.org/10.19106/JMedSci004903201705.

8. Soewondo P, Purnamasari D, Oemardi M, Waspadji S, Soegondo S. Prevalence of metabolic syndrome using NCEP/ATP III criteria in Jakarta, Indonesia: the Jakarta primary non-communicable disease risk factors surveillance 2006. Acta Med Indones. 2010;42:199-203 http://www. inaactamedica.org/archives/2010/ 21063040.pdf.

9. Lim S, Shin H, Song JH, et al. Increasing prevalence of metabolic syndrome in Korea: the Korean National Health and nutrition examination survey for 1998-2007. Diabetes Care. 2011;34:1323-8 https://doi.org/10.2337/dc10-2109.

10. Strauss J, Witoelar F, Sikoki B, Wattie AM. The fourth wave of the Indonesia family life survey : overview and field report volume 1. 2009. microdata. worldbank.org/index.php/catalog/1044/download/20909. 
11. International Diabetes Federation. The IDF consensus worldwide defi nition of the METABOLIC SYNDROME. 2006. https://www.idf.org/e-library/ consensus-statements/60-idfconsensus-worldwide-definitionof-themetabolic-syndrome.

12. Mohamud WNW. Ismail a al-S, Sharifuddin a, et al. prevalence of metabolic syndrome and its risk factors in adult Malaysians: results of a nationwide survey. Diabetes Res Clin Pract. 2011;91:239-45 https://doi.org/10.1016/j. diabres.2010.11.025.

13. Enkh-Oyun T, Kotani K, Davaalkham D, et al. Epidemiologic features of metabolic syndrome in a general Mongolian Population. Metab Syndr Relat Disord. 2015;13:179-86. https://doi.org/10.1089/met.2014.0067.

14. Park S-Y, Park Y-K, Cho K-H, et al. Normal range albuminuria and metabolic syndrome in South Korea: the 2011-2012 Korean National Health and nutrition examination survey. PLoS One. 2015;10:e0125615. https://doi.org/ 10.1371/journal.pone.0125615.

15. Ming J, Xu S, Yang C, et al. Metabolic syndrome and chronic kidney disease in general Chinese adults: results from the 2007-08 China National Diabetes and metabolic disorders study. Clin Chim Acta. 2014;430:115-20. https://doi. org/10.1016/J.CCA.2014.01.004.

16. Khoo CM, Liew CF, Chew SK, Tai ES. The impact of central obesity as a prerequisite for the diagnosis of metabolic syndrome*. Obesity. 2007;15: 262-9. https://doi.org/10.1038/oby.2007.559.

17. Yeh C-J, Chang H-Y, Pan W-H. Time trend of obesity, the metabolic syndrome and related dietary pattern in Taiwan: from NAHSIT 1993-1996 to NAHSIT 2005-2008. Asia Pac J Clin Nutr 2011;20:292-300. http://www.ncbi. nlm.nih.gov/pubmed/21669598

18. Katulanda $P$, Ranasinghe $P$, Jayawardana $R$, Sheriff $R$, Matthews DR. Metabolic syndrome among Sri Lankan adults: prevalence, patterns and correlates. Diabetol Metab Syndr. 2012;4(24) https://doi.org/10.1186/ 1758-5996-4-24

19. Morales DD, Punzalan FER, Paz-Pacheco E, Sy RG, Duante CA. National Nutrition and Health Survey: 2003 group. Metabolic syndrome in the Philippine general population: prevalence and risk for atherosclerotic cardiovascular disease and diabetes mellitus. Diabetes Vasc Dis Res. 2008;5: 36-43 https://doi.org/10.3132/dvdr.2008.007.

20. Ford ES. Prevalence of the metabolic syndrome defined by the international diabetes federation among adults in the U.S. Diabetes Care. 2005;28:2745-9 https://doi.org/10.2337/diacare.28.11.2745.

21. Palaniappan LP, Wong EC, Shin JJ, Fortmann SP, Lauderdale DS. Asian Americans have greater prevalence of metabolic syndrome despite lower body mass index. Int J Obes. 2011;35:393-400. https://doi.org/10. 1038/ijo.2010.152.

22. Hatma RD. Lipid profiles among diverse ethnic groups in Indonesia. Acta Med Indones. 2011;43:4-11 https://www.inaactamedica.org/archives/2011/ 21339539.pdf.

23. Matthews KA, Räikkönen K, Gallo L, Kuller LH. Association between socioeconomic status and metabolic syndrome in women: testing the reserve capacity model. Health Psychol. 2008;27(5):576-83. https://doi.org/ 10.1037/0278-6133.27.5.576.

24. Zhan Y, Yu J, Chen R, et al. Socioeconomic status and metabolic syndrome in the general population of China: a cross-sectional study. BMC Public Health. 2012;12(921) https://doi.org/10.1186/1471-2458-12-921.

25. Lewis GF, Uffelman KD, Szeto LW, Steiner G. Effects of acute hyperinsulinemia on VLDL triglyceride and VLDL apoB production in normal weight and obese individuals. Diabetes. 1993;42:833-42. https://doi.org/10. 2337/DIAB.42.6.833.

26. De Carvalho Vidigal F, Bressan J, Babio N, Salas-Salvadó J. Prevalence of metabolic syndrome in Brazilian adults: a systematic review. BMC Public Health. 2013;13(1198) https://doi.org/10.1186/1471-2458-13-1198.

27. Janszky I, Vatten L, Romundstad P, et al. Metabolic syndrome in Poland the PONS study. Ann Agric Environ Med 2011;18(2):270-272. https://www. aaem.pl/Metabolic-syndrome-in-Poland-the-PONS Study, 71696,0,2.html.

28. Lan Y, Mai Z, Zhou S, et al. Prevalence of metabolic syndrome in China: an up-dated cross-sectional study. PLoS One. 2018;13:e0196012. https:/doi.org/ 10.1371/journal.pone.0196012.

29. Wildman RP, McGinn AP, Kim M, et al. Empirical derivation to improve the definition of the metabolic syndrome in the evaluation of cardiovascular disease risk. Diabetes Care. 2011;34(3):746-8 https://doi.org/10.2337/dc10-1715.

30. WHO Expert Consultation. Appropriate body-mass index for Asian populations and its implications for policy and intervention strategies.
Lancet (London, England). 2004;363:157-63 https://doi.org/10.1016/S01406736(03)15268-3.

31. Sumner AE, Zhou J, Doumatey A, et al. Low HDL-cholesterol with Normal triglyceride levels is the Most common lipid pattern in west Africans and African Americans with metabolic syndrome: implications for cardiovascular disease prevention. CVD Prev Control. 2010;5:75-80. https://doi.org/10.1016/ j.cvdpc.2010.07.003.

32. Boudreau DM, Malone DC, Raebel MA, et al. Health care utilization and costs by metabolic syndrome risk factors. Metab Syndr Relat Disord. 2009;7:305-14 https://doi.org/10.1089/met.2008.0070.
Ready to submit your research? Choose BMC and benefit from:

- fast, convenient online submission

- thorough peer review by experienced researchers in your field

- rapid publication on acceptance

- support for research data, including large and complex data types

- gold Open Access which fosters wider collaboration and increased citations

- maximum visibility for your research: over $100 \mathrm{M}$ website views per year

At BMC, research is always in progress.

Learn more biomedcentral.com/submissions 